J. Clin. Chem. Clin. Biochem.

Vol. 24, 1986, pp. 293-298

(C) 1986 Walter de Gruyter \& Co.

Berlin $\cdot$ New York

\title{
The Use of Bioluminescence to Evaluate the Influence of Chemotherapeutic Drugs on ATP-Levels of Malignant Cell Lines
}

\author{
By R. Kuzmits
}

II. Department of Medicine

H. Rumpold

Department of Experimental Pathology

M. M. Müller and G. Schopf

II. Department of Surgery,

University of Vienna, Austria

(Received July 19/November 15, 1985)

Dedicated to Prof. Dr. E. Kaiser on the occasion of his 60th birthday

Summary: Influence of various cytostatic agents on intracellular ATP concentrations of malignant cell lines was studied. The HL-60 promyelocytic cell line, the SW-480 cell line, derived from an adenocarcinoma of the colon and the SW-620 cell line, derived from a lymphonodal metastasis of the colon carcinoma, were investigated. Cell lines were incubated with cytostatic agents and changes in intracellular ATP concentrations were measured after various incubation times by means of bioluminescence.

A marked fall in intracẹllular ATP concentrations was observed, when HL-60 cells were incubated with drugs used in clinical protocols for treatment of acute leukaemia (daunorubicin, vinblastine, vincristine), whereas only a slight decrease of ATP concentrations was measured after incubation with bleomycin, dacarbazin and prednisolone. The decrease in intracellular ATP concentrations of SW-480 and SW-620 cells was much less pronounced after incubation with cytostatic agents compared to the HL-60 cells. This is in accordance with the clinical experience of the known resistance of colon carcinoma against cytostatic agents. Dose-response curves were obtained for the single cytostatic agents. Comparison of intracellular ATP concentrations and cell viability as determined by the trypan blue and eosin dye exclusion test showed that the trypan blue dye exclusion test underestimated cell kill compared to the eosin dye exclusion test and the bioluminescence assay.

Anwendung der Biolumineszenz zur Bestimmung des. Einflusses von Chemotherapeutika auf ATP-Konzentrationen maligner Zellinien

Zusammenfassung: Der Einfluß verschiedener Cytostatika auf intrazelluläre ATP-Konzentrationen maligner Zellinien wurde untersucht. Die HL-60 promyelocytäre Zellinie, die SW-480, die aus einem Adenokarzinom des Colons und die SW-620, die aus einer Lymphknotenmetastase desselben Patienten isoliert wurden, wurden verwendet. Die Zellinien wurden mit Zytostatika inkubiert und die intrazellulären ATP-Konzentrationen nach verschiedenen Inkubationszeiten unter Anwendung der Biolumineszenz bestimmt. 
Nach Inkubation der HL-60 Zellen mit Cytostatika, die auch in klinischen Therapieprotokollen für akute Leukämien angewendet werden (Daunorubicin, Vinblastin, Vincristin), wurde ein deutlicher Abfall der intrazellulären ATP-Konzentrationen beobachtet, während nach Inkubation mit Bleomycin, Dacarbazin oder Prednisolon nur geringgradige Veränderungen des ATP-Gehaltes gemessen wurden. Entsprechend der klinischen Erfahrung über die bekannte Resistenz von Colonkarzinomen gegenüber Cytoșţatika war der Abfall intrazellulärer ATP-Konzentrationen bei SW-480- und SW-620-Colonkarzinomzellinien nach Inkubation mit Zytostatika viel geringer ausgeprägt als bei HL-60-Zellen. Für die einzelnen Cytostatika wurden DosisWirkungskurven ermittelt. Der Vergleich intrazellulärer ATP-Konzentrationen mit der Zellviabilität, die mit Farbausschlußtests mit Eosin oder Trypanblau bestimmt wurde, zeigte, daß der Zelltod mit dem TrypanblauFarbausschlußtest unterbewertet wird gegenüber der Bestimmung des Zelltodes mit dem Eosin-Farbausschlußtest oder dem Biolumineszenz-Assay für ATP.

\section{Introduction}

Analysis of the intracellular concentration of highenergy phosphates can be used to measure the energy status of cells. Since cells maintain their ATP concentration nearly constant under physiological conditions, metabolic disturbances, e. g. by toxic agents, will result in a rapid decrease of the total amount of ATP $(1,2)$. Furthermore, cell death is accompanied by a rapid and complete loss of ATP $(3,4)$. It should therefore be possible to investigate the influence of cytostatic agents on cancer cell metabolism by measuring the ATP concentrations in malignant cells. This might be important for pretherapeutic testing of cytostatic agents in cancer patients. In recent years several methods including dye exclusion tests (5), isotopic incorporation tests using labeled thymidine (6) and colony forming tests (7) have been applied in pretherapeutic drug sensitivity testing.

In the present study changes in the ATP content of the SW-480 and SW-620 adenocarcinoma cell line and of HL-60 promyelocytic cells, exposed to various cytostatic agents, were measured. Intracellular ATP concentrations were determined using firefly bioluminescence. Dose-response curves were derived for various cytostatic agents. Intracellular ATP content and dye exclusion tests using trypan blue and eosin for determination of drug induced cytotoxicity were compared.

\section{Materials and Methods}

Cell lines

HL-60 are a unique human cell line that was developed from peripheral blood leukocytes of a patient with acute promyelocytic leukaemia by Collins et al. (8). The cultured cells display distinct morphological and histochemical myeloid characteristics.

SW-480 was isolated from a primary adenocarcinoma arising in the colon, whereas SW-620 was isolated from a lymph node when the cancer recurred with wide spread metastasis. Both cell lines were derived from the same patient (9).
All in vitro experiments with HL-60 cells were carried out in medium RPMI 1640 (RPMI 1640 with 2.0 g/l sodium bicarbonate without glutamine, Flow Laboratories, Irvine, U. K.) containing $0.002 \mathrm{~mol} / 1$ glutamine, $100 \mathrm{ml} / \mathrm{l}$ foetal calf serum and $0.1 \mathrm{~g} / 1$ gentamycin.

Colon tumour cell lines were cultivated in Leibovitz L 15 medium supplemented with $100 \mathrm{ml} / 1$ foetal calf serum, $10 \mu \mathrm{g} / \mathrm{l}$ insulin and $10 \mathrm{mg} / \mathrm{l}$ cortisol.

\section{Cytotoxicity testing}

Prior to incubations with chemotherapeutic agents cells were harvested and resuspended in medium to yield a cell count of $0.1 \times 10^{9} / 1$. Sterile plastic or siliconized glass ware was used in all procedures. The cell suspensions were distributed into test tubes, and cytostatic agents were dissolved in medium and added to the cell suspensions to give a final drug concentration shown in table 1 . Drug concentrations were the same as used in clinical protocols, but calculated as if they would distribute only in the extracellular fluid. From the test tubes the cell suspensions were distributed inte micro titer plates, and the drugs remained for the entire culture period in the test plates.

To study dose-response relationșhips cytostatic agents were diluted up to $1: 50$ (maximal concentrations are shown in tab. 1) in culture medium and added to the cell suspensions.

Treated cells and cytostatic-free control incubations were held under tissue culturing conditions $\left(5 \% \mathrm{CO}_{2}\right.$ atmosphere humidified incubator at $37^{\circ} \mathrm{C}$ ). Intracellular ATP was determined in the specimens and in drug-free control incubations after various culture periods. Each value represents the mean of a triple determination.

\section{ATP determination}

Intracellular ATP concentrations in HL-60 and colon carcinoma cell lines were determined by the firefly bioluminescence method. To liberate ATP from the cells, the nonionic detergent, ethoxy alkylphenol (NRS ${ }^{\circledR}$, Lumac, Basel, Switzerland), was used. Cell suspensions were diluted $1: 5$ in $0.02 \mathrm{~mol} / 1$ tris buffer pH 7.75 containing $2 \mathrm{mmol} / 1$ EDTA, and $100 \mu \mathrm{l}$ NRS ${ }^{\top}$ was added to $25 \mu$ l of the diluted cell suspension. The reaction was started by addition of $100 \mu$ l of a luciferin-lüciferase suspension (Lumit ${ }^{\circledR}$ PM, Lumac, Basel, Switzerland). The number of photons released subsequently by the luciferin-luciferase reaction with ATP was measured using the "Biocounter TM-M200" from Lumac (Lumac, Basel, Switzerland). The digitally displayed integrated relative light units were recorded and the ATP concentration was obtained using an internal standardization technique. 
Tab. 1. Drug concentrations in vitro.

\begin{tabular}{|c|c|c|c|}
\hline Drug (INN) & Registered trade mark & Manufacturer & $\begin{array}{l}\text { Concentration } \\
\text { ( } \mu \mathrm{mol} / \mathrm{l} \text { cell } \\
\text { suspension) }\end{array}$ \\
\hline Doxorubicin & Adriblastin & $\begin{array}{l}\text { Farmitalia, Carlo Erba, Freiburg i. B., } \\
\text { FRG }\end{array}$ & 11.4 \\
\hline Bleomycin & Bleomycin Lundbeck & H. Lundbeck, Kopenhagen, Denmark & 1.4 \\
\hline 4-Hydroperoxy-cyclophosphamide & $\left.-^{*}\right)$ & Asta, Brackwede, FRG & 119.3 \\
\hline Cytarabine & Alexan & Mack, Illertissen, FRG & 205.6 \\
\hline Dacarbazin & DTIC-Dome & $\begin{array}{l}\text { Miles Laboratories, Stoke Poges, } \\
\text { Bucks., U.K. }\end{array}$ & 181.1 \\
\hline Daunorubicin & Daunoblastin & $\begin{array}{l}\text { Farmitalia, Carlo Erba, Freiburg i. B., } \\
\text { FRG }\end{array}$ & 11.7 \\
\hline Fluorouracil & Fluoro-Uracil "Roche" & $\begin{array}{l}\text { Hoffmann - La Roche, Basel, } \\
\text { Switzerland }\end{array}$ & 507.3 \\
\hline Mercaptopurine & 6-Mercaptopurine & $\begin{array}{l}\text { Sigma Chemical Co., St. Louis, Mo., } \\
\text { U.S. A. }\end{array}$ & 78.1 \\
\hline Mitomycin & Mitomycin C “Kyowa" & Kyowa Hakko Kogyo, Tokio, Japan & 1.2 \\
\hline Prednisolone & Prednisolon "Linz" & Chemie-Linz, Linz, Austria & 16.7 \\
\hline Etoposide & Vepesid & Bristol-Myers, Bergisch-Gladbach, FRG & 17.0 \\
\hline Vinblastine & Velbe & Eli-Lilly, Giessen, FRG & 0.9 \\
\hline Vincristine & Oncovin & Eli-Lilly, Giessen, FRG & 0.2 \\
\hline
\end{tabular}

*) We thank Dr. V. Lierter from ASTA, Brackwede, FRG, for providing this substance, which is a derivative of cyclophosphamide active in vitro.

Daily determination of the ATP standard (500 fmol per test) showed a CV of $5.4 \%$. For the precision of ATP determinations in cell extracts a CV (within a run) of $3 \%$ was calculated.

\section{Dye exclusion tests}

Dye exclusion tests using trypăn blue (10) and eosin (11) were performed to estimate cell death following exposure to cytotoxic drugs. Cell suspensions were examined under a bright field microscope, 100 cells were counted for each experimental value recorded. Viable cells were identified by their ability to exclude dye, nonviable cells were stained by the dye.

\section{Results}

To evaluate the sensitivity and linearity of the ATP determination, cell suspensions were diluted down to 156 cells per test, using $0.02 \mathrm{~mol} / 1$ tris buffer $\mathrm{pH} 7.75$, containing $2 \mathrm{mmol} / 1$ EDTA. Good linearity from $156-1250$ cells per test was observed with all 3 cell types studied (fig. 1). Mean ATP concentrations in the SW-480 cells ( 5 experiments) were $9.1 \pm 1.46$ (SD) $\mathrm{fmol} /$ cell, in SW-620 (5 experiments) $12.1 \pm$ $1.57 \mathrm{fmol} / \mathrm{cell}$ and in HL-60 cells (5 experiments) $4.4 \pm 0.22 \mathrm{fmol} /$ cell. HL-60 cells showed a marked decrease in intracellular ATP when doxorubicin, 4hydroperoxycyclophosphamide, vinblastine and vincristine were added to the cell suspensions (fig. 2), the drugs being present during the whole culture period (up to 6 days). No significant decrease in intracellular ATP was found when HL-60 cells were incubated with bleomycin, dacarbazine or prednisolone. Since drug-induced cell death was indicated within a 2-day culture period, subsequent experiments were conducted over a 48-hour incubation

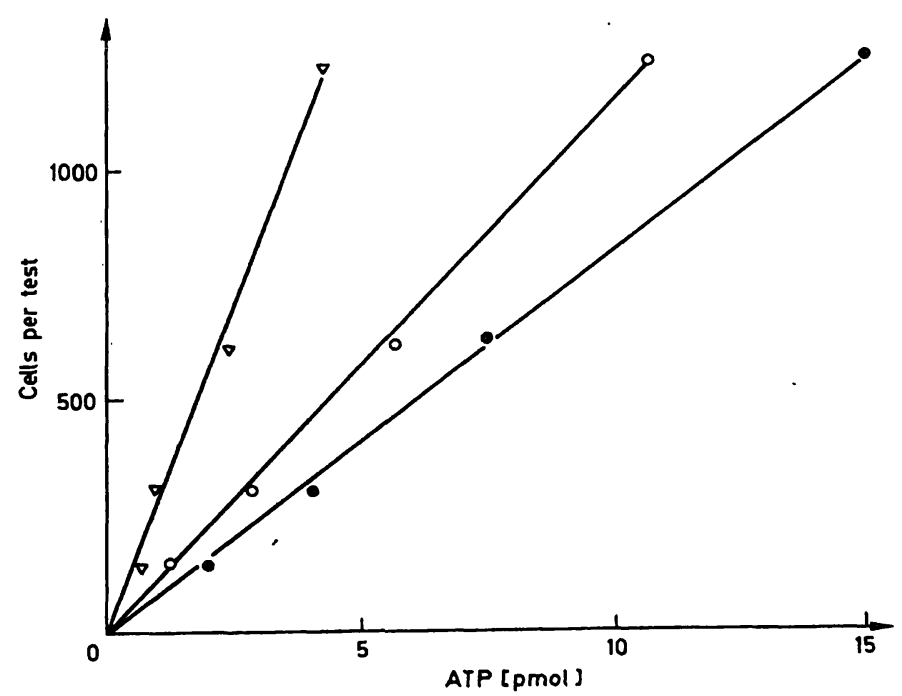

Fig. 1. Determination of intracellular ATP concentration in HL-60 promyelocytic cells $(\nabla-\nabla)$, in SW-480 (O-O) and $\mathrm{SW}-620(-\bullet)$ colon carcinoma cell lines using firefly bioluminescence. 
period. ATP concentrations in the drug-free control incubations of HL-60, SW-480 and SW-620 cells over a culture period of 48 hours are shown in figure 3.

Dose-response curves were derived for drugs which showed an effect on intracellular ATP (fig. 4). Sensitivity of SW-480 (fig. 5) and SW-620 (fig. 6) colon carcinoma cell lines against cytostatic agents was

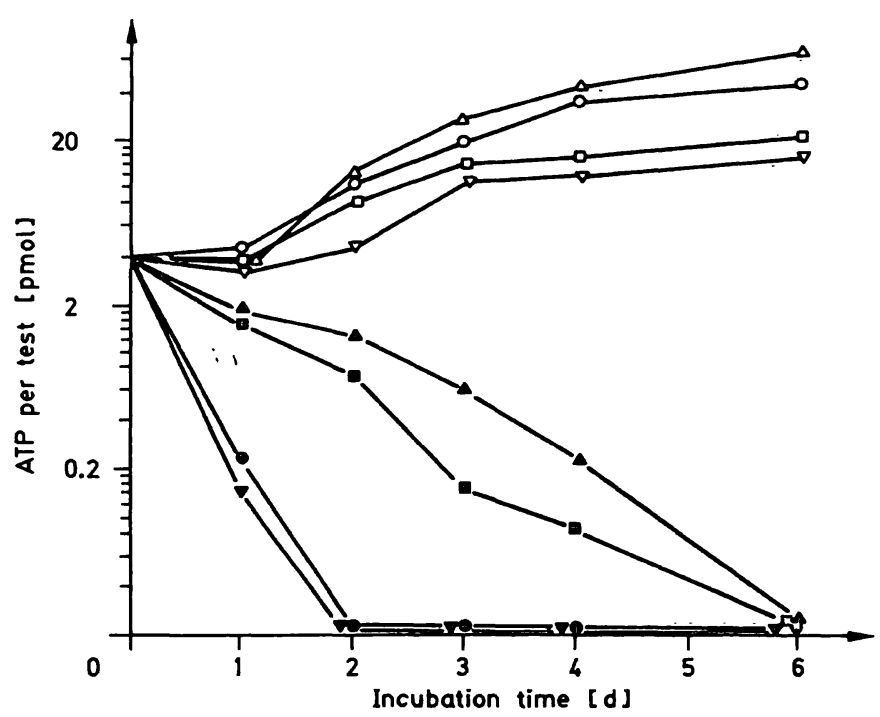

Fig. 2. Influence of various cytostatic agents on ATP concentrations in HL-60 promyelocytic cells (pmol ATP/25 $\mu \mathrm{l}$ diluted cell suspension). Drug concentrations used in the experiments are listed in tab. 1. ( $0-0$ drug-free control incubation; $\Delta-\Delta$ prednisolone; $\square-\square$ bleomycin; $\nabla-\nabla$ dacarbazine; $\mathbf{\Delta}-\mathbf{\Delta}$ vincristine; $\mathbf{\Delta}-\mathbf{\square}$ vinblastine; $0-0$ doxorubicin; $\nabla-\nabla$ 4-hydroperoxy-cyclophosphamide).

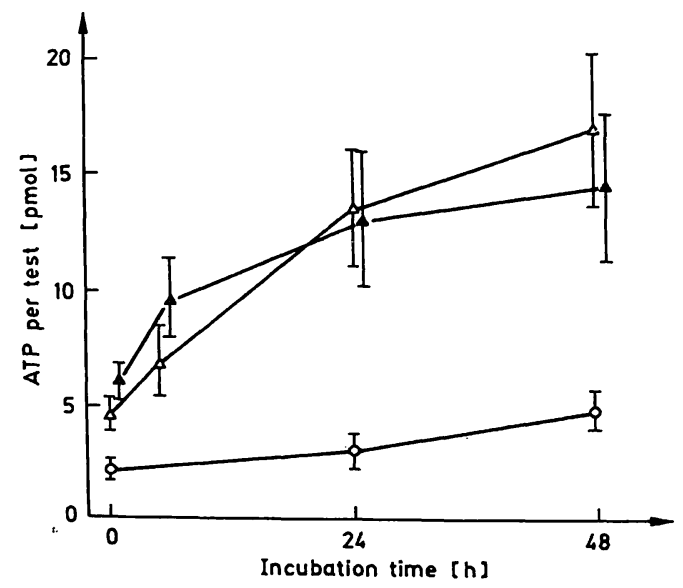

Fig. 3. ATP concentrations $(\bar{x} \pm S D)$ in the drug-free control incubations of HL-60 ( $N=5 ; 0-0), S W-480(n=5$; $\Delta-\Delta)$ and SW-620 cells $(n=5 ; \Delta-\Delta)$ over a 48 hour culture period (pmol ATP/25 $\mu$ l diluted cell suspension). much less pronounced compared to HL-60 cells (fig. 7). Comparison of intracellular ATP concentrations and cell viability, as determined by the trypan-blue and eosin-dye exclusion tests, showed that there was a general agreement between the tests, but the trypan blue dye exclusion test underestimated cell kill compared to the eosin-dye exclusion test and the bioluminescence assay (fig. 8).

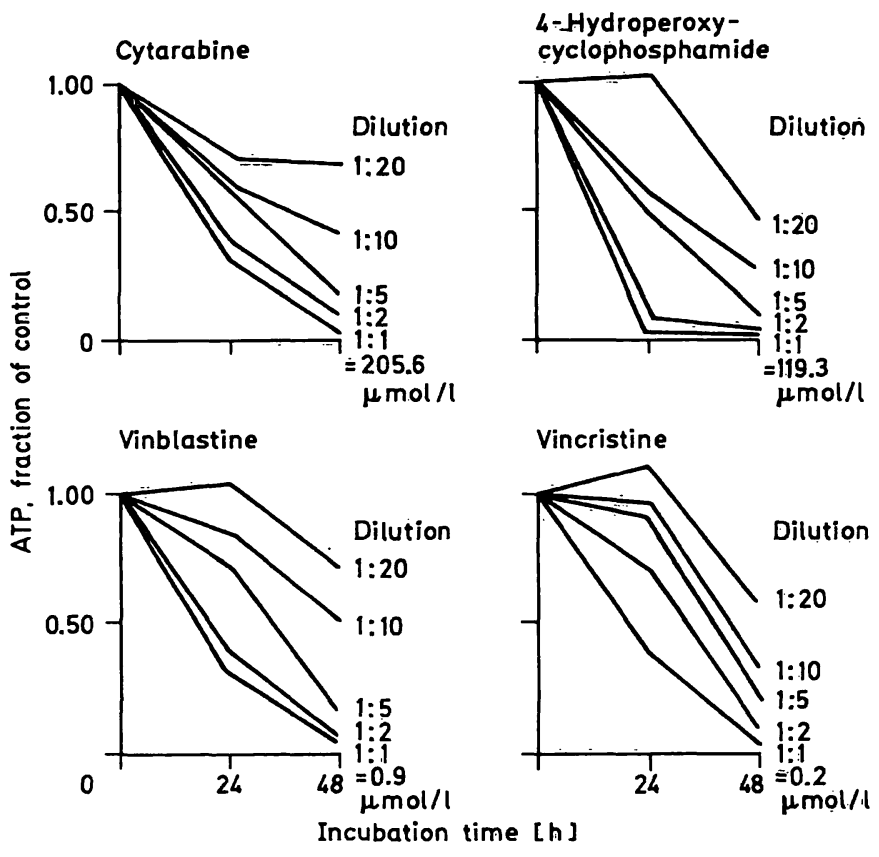

Fig. 4. Dose-response curves for cytosine arabinoside, 4-hydroperoxy-cyclophosphamide, vinblastine and vincristine in HL-60 promyelocytic cells. (For highest drug concentrations cf. also tab. 1; these drug concentrations were diluted as indicated.

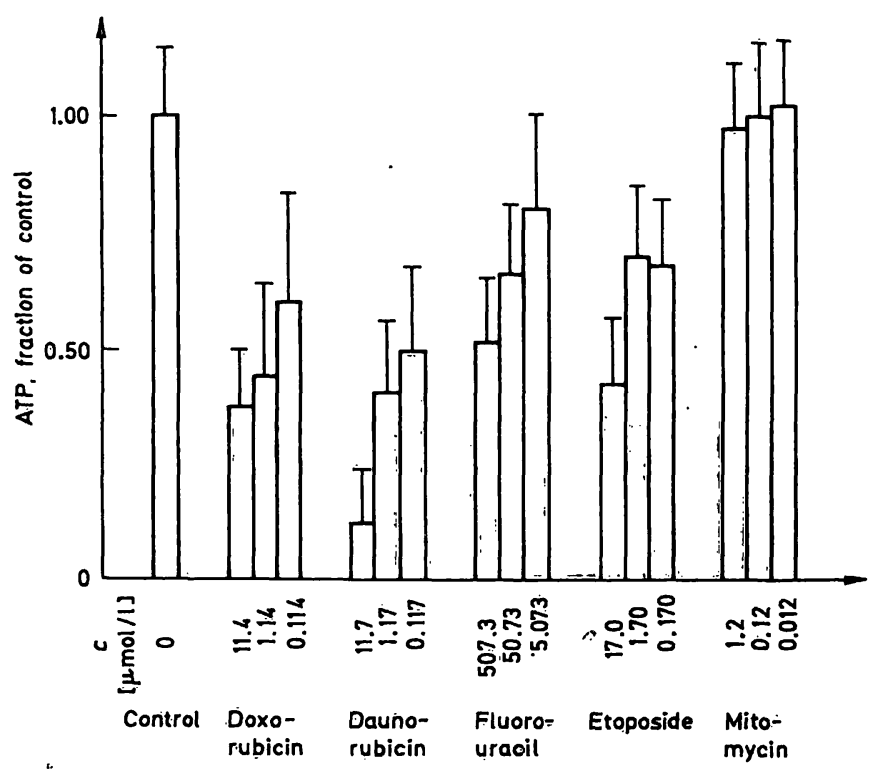

Fig. 5. ATP concentrations of SW-480 colon carcinoma cell lines after a 48-hour incubation period with cytostatic agents (cf. tab. 1) (5 experiments + SD). 


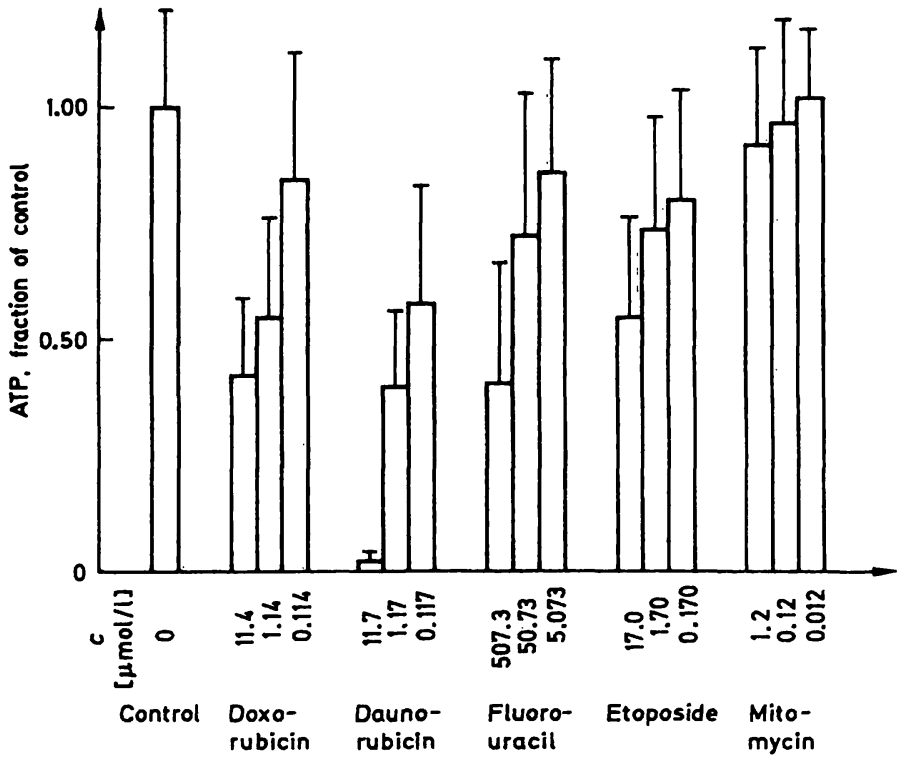

Fig. 6. ATP concentrations of SW-620 colon carcinoma cell lines after a 48-hour incubation period with cytostatic agents (cf. tab. 1) (5 experiments + SD).

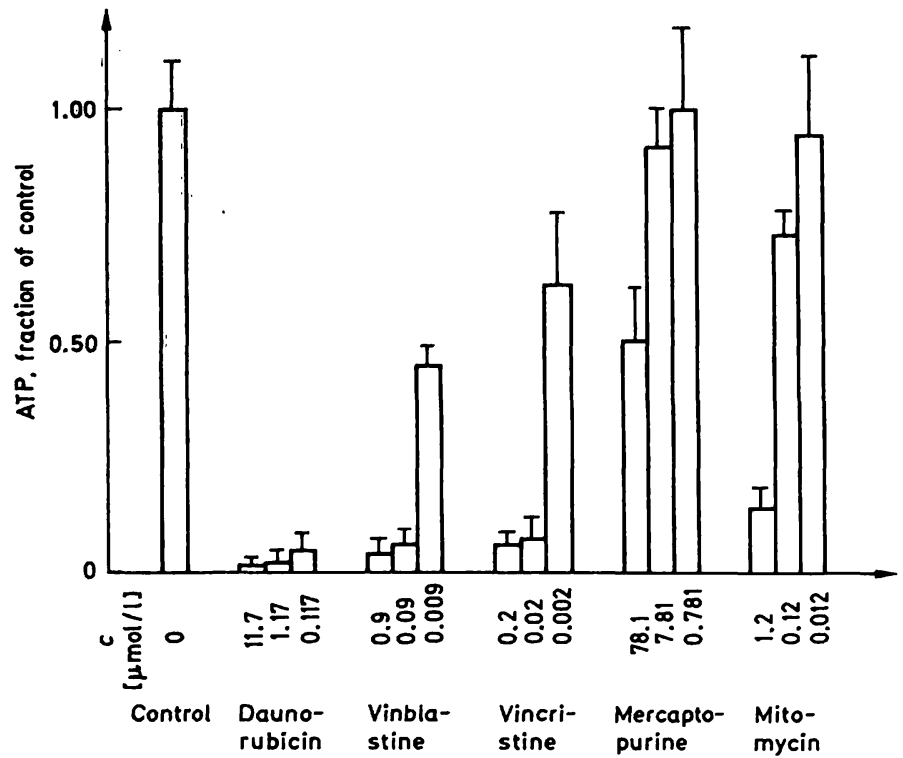

Fig. 7. ATP concentrations of HL-60 promyelocytic cells after a 48-hour incubation time with cytostatic agents (cf. tab. 1) (5 experiments $+\mathrm{SD})$.
Doxorubicin

ATP bioluminescence assay

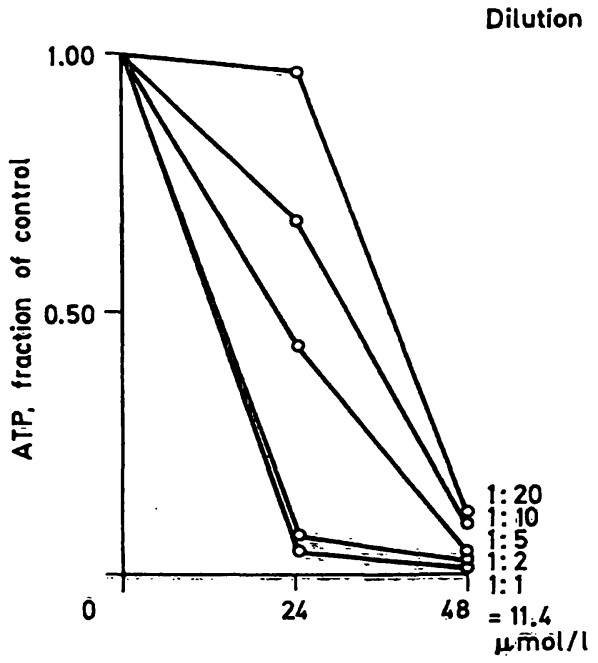

Doxorubicin

Eosin dye exclusion test

Dilution

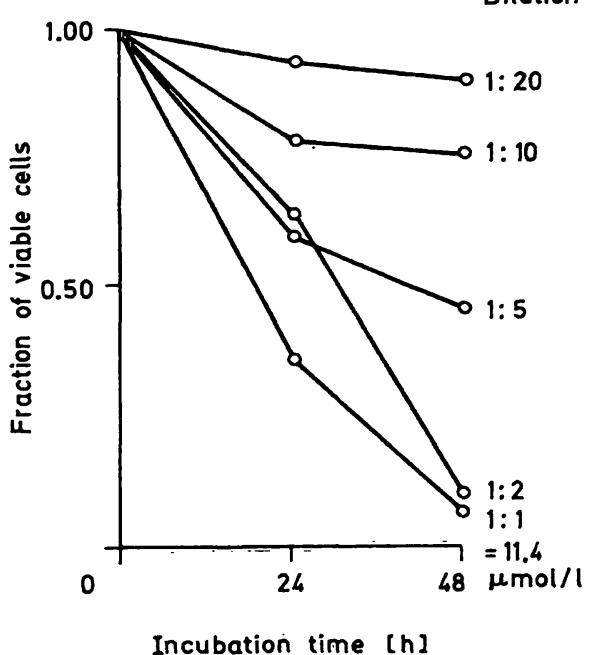

Doxorubicin

Trypan blue dye exclusion test Dilution

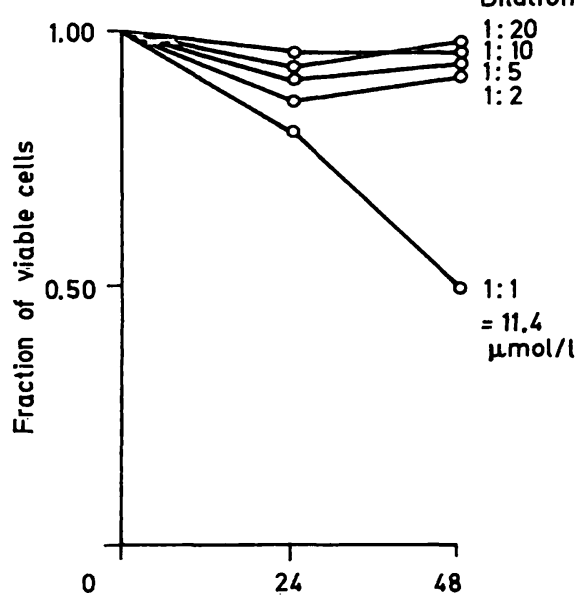

Fig. 8. Comparison of intracellular ATP concentrations and cell viability as determined by eosin and trypan blue dye exclusion tests in HL=60 cells after a 48 -hour incubation period with doxorubicin (cf. tab. 1).

\section{Discussion}

Various test systems have been designed to detect drug-induced cytotoxicity in malignant cells in vitro. A classic method for testing the loss of reproducibility of cancer cells is the colony-forming technique (7). However, agar cloning assays are time consuming and technical disadvantages limit their application in preclinical drug screening (12).

Determination of drug-induced cytotoxicity was also performed using the dye exclusion assays; Durkin et al. (5) reported a good correlation between the in vivo responsiveness and the in vitro results using the trypan blue dye exclusion assay. Weisenthal et al. (13) compared a novel fast green dye exclusion method with a clonogenic assay. Both assays were in qualitative agreement for the drugs tested, but the standard agar cloning assay gave somewhat higher estimates of cell kill than the dye exclusion method. The main drawback of dye exclusion assays is the impossibility of detecting the various degrees of morbidity which can occur in cells from the vital status to cell death. 
Application of firefly bioluminescence provides a rapid and sensitive method to determine intracellular ATP in cells. The method is sensitive enough to detect ATP concentrations up to $10^{-18} \mathrm{~mol}$ ATP in a sample (14). As the total amount of ATP in the samples was rather low, this method proved sufficiently sensitive and enabled rapid and precise determinations of ATP in only small amounts of cell material (e. g. 500 cells per test). In addition, the determination is very rapid, results of one determination being obtained within 10 seconds. However, the method requires an optimal single cell suspension, but can also be applied to solid tumours if one succeeds in separating the cell associations.

Assessment of other high energy phosphates, such as ADP, AMP and cAMP, is also possible by means of bioluminescence. Especially the adenylate energy charge, which can be calculated from the ATP, ADP and AMP concentrations, indicates very accurately the metabolic state of the cells, but its determination requires much more time. As the method used should enable rapid pretherapeutic screening of cytostatic drugs in cancer patients, we limited our efforts to the measurement of the most important component, ATP.

Incubation of HL-60 cells with cytostatic drugs used in clinical protocols for treatment of leukaemia patients led to a marked decrease in intracellular ATP concentrations. The decrease in intracellular ATP concentrations was much less pronounced after incubation with various cytostatic agents in SW-480 and

\section{References}

1. Mills, D. C. B. (1973) Nature 243, 220-222.

2. Loos, J. A. \& Prins, H. K. (1970) Biochim. Biophys. Acta 201, 185-195.

3. Hopf, U. K., Meyer zum Büschenfelde, H., Groth, U. \& Freudenberg, J. (1974) Res. Exp. Med. 163, 199-209.

4. Glick, D. (1977) Clin. Chem. 23, 1465-1471.

5. Durkin, W. J., Ghanta, V. K., Balch, C. M., Davis, D. W. \& Hiramoto, R. N. (1979) Cancer Res. 39, 402-407.

6. Volm, M., Wayss, K., Kaufmann, M. \& Mattern, J. (1979) Europ. J. Cancer 15, 983-993.

7. Salmon, S. E., Hamburger, A. W., Soehnlein, B. J., Durie, B. G. M., Alberts, D. S. \& Moon, T. C. (1978) N. Engl. J. Med. 298, $1321-1327$.

8. Collins, J. S., Gallo, R. C. \& Gallagher, R. E. (1977) Nature $270,347-349$.
SW-620 adenocarcinoma cells. No differences in the effect of cytostatics on intracellular ATP concentrations were observed between the cell line derived from the primary tumour (SW-480) and the cell line derived from the metastasis (SW-620). These results are in accordance with the clinical experience of the known resistance of colorectal carcinomas against most cytostatic agents.

A clear dose-response relationship could be demonstrated for various cytostatic agents.

Comparison of the bioluminescence assay and dye exclusion tests showed that comparable results were obtained with the bioluminescence assay and the eosin dye exclusion test, whereas cell death was underestimated by the trypan blue dye exclusion test. Cell damage is indicated by a drop in intracellular ATP concentrations, which makes it possible to obtain a result between 6 and 25 hours earlier than by the trypan blue dye exclusion test.

Determination of drug-induced cytotoxicity by the firefly bioluminescence assay might be used to detect resistance or sensitivity of leukaemic cells to cytostatic agents in vitro. Application of the test for solid tumours is possible, but an optimal single cell suspension is required in this test system. Further work will be necessary to evaluate the in vitro results and the in vivo responsiveness in cancer patients. Studies on the application of the test system for pretherapeutic drug testing in acute leukaemia are in progress.
9. Leibovitz, A., Stinson, J. C., McCombs, W. B., McCoy, C. E., Mazur, K. C. \& Mabry, N. D. (1976) Cancer Res. $36,4562-4569$.

10. Hoskins, J. M., Meynell, G. G. \& Sanders, F. K. (1956) Exp. Cell Res. 11, 297-301.

11. Hanks, J. H. \& Wallace, J. H. (1958) Proc. Soc. Exp. Biol. Med. 98, 188-192.

12. Selby, P., Buick, R. N. \& Tannock, I. (1983) N. Engl. J. Med. 308, 129-134.

13. Weisenthal, L. M., Dill, P. L., Kurnick, N. B. \& Lippman M. E. (1983) Cancer Res. 43, 258-264.

14. Wettermark, G., Thymne, H., Brolin, S. E. \& Petterson, B. (1975) Anal. Biochem. 63, 293-302.

Dr. Rudolf Kuzmits

II. Department of Medicine

Garnisongasse 13

A-1090 Vienna 